\title{
Mineral analysis of dry extracts from the seeds of the plant Silybum marianum (L. Gaertner) introduced in Uzbekistan
}

\author{
Qayumov Feruz, Sobir o'g li $^{1}$ \\ ${ }^{I}$ Assistant of the Department of Biotechnology, Tashkent Pharmaceutical Institute. \\ Tuxtayev Farhod Hakimovich ${ }^{2}$ \\ ${ }^{2}$ Tashkent Pharmaceutical Institute \\ Senior lecturer, The department of biotechnology.
}

\begin{abstract}
Silybum marianum (L.) Gaerth. (Asteraceae) is a valuable medicinal plant In the domestic and foreign literature the following pharmacological properties of the medicinal forms from Silybum marianum are described: antioxidant, antitoxic, hemostatic, hepatoprotective, detoxification, choleretic, anti-inflammatory, wound healing, reparative, laxatives, tonic, improving digestion, cholekinetic, cholesecret [1,2]. In Uzbekistan, the development of products for functional and therapeutic-preventive purposes for preventing various diseases and strengthening protective functions body, reducing the risk of exposure to harmful substances, including for the population living In ecologically unfavorable zones [3]. Macro and microelement analyzes of dry extract from asparagus seeds were performed. It was found that the extract contained balanced macro and microelements. Based on the results of the experiments, the product was recommended for use in biologically active supplements.
\end{abstract}

Keywords: Milk Thistle seeds, dry extract, macro and micronutrients, Iron, Biologically active supplements.

\section{INTRODUCTION}

The amount of macro-and micronutrients contained in biologically active supplements is important for living organisms, especially human health, as they are a nutrient component involved in various physiological functions. In a healthy human body, Mendeleev has a number of elements that are present in the periodic table of elements. They play a key role in the building function of the body, especially in the structure and proper formation of bones. Minerals are important in maintaining the acid-base balance in the body, the formation of the required amount of hydrogen ions in bones and tissues, as well as in interstitial and intercellular fluids, as well as their osmotic properties, the normal course of metabolism. Minerals are a component of intercellular fluids and are involved in the formation of cells in the blood and bone, in the regulation of the nervous system, in the regulation of muscle as well as cardiovascular muscle tone. Minerals such as vitamins direct coenzymes and play an important role in the body's growth, regeneration, and energy production. All enzymatic processes present in the body are carried out at the expense of micro and macronutrients, so they are very important in the processing of minerals, vitamins and other nutrients. [4] The concentration of mineral elements in the human body is not uniform.

\section{MAIN PART}

When the minerals present in human tissue are measured in grams, the concentration of many other mineral elements in the body is less than 1: 100,000. Elements in which the chemical elements measured in grams in the human body are present in very small concentrations are called micronutrients.

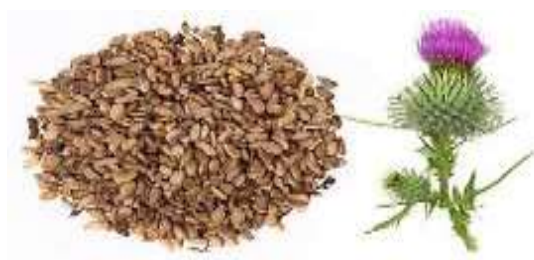

1-fig. Silybum marianum (L.)
The mineral elements in the tissues of the body change significantly with age. During the rapid growth of the human body and the development of stature, the amount of microelements also increases and slows down or stops at the age of 17-20 years. The following table shows the mineral content of the human body with an average weight of $70 \mathrm{~kg}$. [5] Lack of micro and macro elements in the human body leads to rapid disease and convulsions.

\begin{tabular}{|l|l|l|l|l|l|c|l|}
\hline $\begin{array}{l}\text { Chemical } \\
\text { element }\end{array}$ & gr & $\%$ & $\begin{array}{c}\text { Chemical } \\
\text { element }\end{array}$ & gr & $\%$ & $\begin{array}{c}\text { Chemical } \\
\text { element }\end{array}$ & gr \\
\hline Calcium & 1510 & 2.2 & Sodium & 105 & 0.15 & Manganese & remnants \\
\hline Phosphorus & 540 & 1.2 & Magnesium & 70 & 0.1 & Cobalt & remnants \\
\hline Potassium & 245 & 0.35 & Iron & 3.5 & 0.005 & Chrome & remnants \\
\hline Sulfur & 105 & 0.15 & Zinc & 1.75 & 0.00025 & Molybdenum & remnants \\
\hline Chlorine & 105 & 0.15 & Copper & 0.07 & 0.00011 & & \\
\hline
\end{tabular}

The fruits of the milk thistle have been used to treat a number of diseases for over 2,000 years. It is widely 
used in practice as a hepatoprotective agent, especially in liver diseases. Drugs based on milk thistle extract are used in the regeneration of the liver, as an antioxidant, anti-inflammatory and hepatoprotective agent in the treatment of hepatitis, cirrhosis of the liver. In addition, the dried extract of gum thistle fruit has been studied in experiments to show that its beneficial side in the fight against viruses and tumors can be an effective tool in preventing damage to the body from chemotherapy. [6] It should also be noted that the analysis of mineral elements in plants is one of the most complex methods of analysis and requires the use of highprecision approaches and methods. At present, the implementation of a number of effective methods that provide fast and high accuracy for the analysis of trace elements has opened up a wide range of possibilities in this regard.

\section{MATERIALS AND METHODS}

Analysis of macro and microelements in samples of dry extract from the fruit of Milk thistle was carried out in the laboratory of the Research Institute of Bioorganic Chemistry named after Sadikov under the Academy of Sciences of the Republic of Uzbekistan.

Method of quantitative determination of micro and macro elements by inductive method coupled plasma mass spectrometry (ICP-MS)., Appliances and utensils used: ISPMSNEXION-2000 or similar mass spectrometer ., Microwave decomposition device (Germany) or similar., Teflon autoclaves

Volumetric flasks ., Reagents used: multi-element standard No. 3 (for 29 elements for MS) standard for $-\mathrm{Hg}$ (mercury) nitric acid (c / h) bidistilled water hydrogen peroxide (c / h) argon (gas purity 99.995\%)

\section{EXPERIMENTAL PART}

Dry extract from Milk thistle seeds was obtained by modern accelerated method. The dry extract of asparagus seeds is a light yellow powder with a characteristic odor.

0.0500-0.5000 g, an accurate sample of the test substance is weighed on an analytical balance and transferred to Teflon autoclaves. Then the autoclaves are filled with an appropriate amount of purified concentrated mineral acids (nitric acid (chemically pure) and hydrogen peroxide (chemically pure)). The autoclaves are closed and placed on a Berghofc microwave digester with the MWS-3 + software or a similar type of microwave digester. Determine the decomposition program based on the type of test substance, indicate the degree of decomposition and the number of autoclaves (up to $12 \mathrm{pcs}$ ). After decomposition, the contents in the autoclaves are quantitatively transferred into 50 or $100 \mathrm{ml}$ volumetric flasks and the volume is adjusted to the mark with $0.5 \%$ nitric acid.

The determination of the substance under study is carried out on an ISPMS device or a similar device, the optics of an emission spectrometer with an inductively coupled argon plasma. In the method of determination, indicate the optimal wavelength of the determined micro or macro elements, at which they have the maximum emission.In the construction of the sequence of analyzes, indicate the amount in $\mathrm{mg}$ and the degree of its dilution in ml. After receiving the data, the true quantitative content of the substance in the test sample is automatically calculated and entered by the device in the form of $\mathrm{mg} / \mathrm{kg}$ or $\mu \mathrm{g} / \mathrm{g}$ with error limits - RSD in $\%$.

\section{RESULT AND DISCUSSIONS}

Quantitative analysis of samples showed a large amount of phosphorus - up to $9477.017 \mathrm{mg} / \mathrm{kg}$, potassium up to $9469.416 \mathrm{mg} / \mathrm{kg}$, calcium - up to $6620.220 \mathrm{mg} / \mathrm{kg}$, magnesium - up to $3741.564 \mathrm{mg} / \mathrm{kg}$, phosphorus - up to $9477.017 \mathrm{mg} / \mathrm{kg}$, sodium - $644.594 \mathrm{mg} / \mathrm{kg}$ and these elements were found to constitute the main elemental content. The composition of the elements is as follows: sulfur - up to $556.628 \mathrm{mg} / \mathrm{kg}$, iron - up to $223.128 \mathrm{mg} / \mathrm{kg}$, silicon - up to $195.841 \mathrm{mg} / \mathrm{kg}$, aluminum - up to $79.572 \mathrm{mg} / \mathrm{kg}$, boron - up to $44.421 \mathrm{mg}$ / kg, zinc - $39.995 \mathrm{mg} / \mathrm{kg}$ up to $26.577 \mathrm{mg} / \mathrm{kg}$ of strontium, up to $24.981 \mathrm{mg} / \mathrm{kg}$ of copper, up to 16.816 $\mathrm{mg} / \mathrm{kg}$ of manganese, up to $8.891 \mathrm{mg} / \mathrm{kg}$ of titanium, up to $6.699 \mathrm{mg} / \mathrm{kg}$ of barium, up to $5.647 \mathrm{mg} / \mathrm{kg}$ of rubidium , chromium-4,296 $\mathrm{mg} / \mathrm{kg}$ each.The amount of ultra microelements is as follows: Nickel - up to $1.953 \mathrm{mg} / \mathrm{kg}$, selenium - up to $0.253 \mathrm{mg} / \mathrm{kg}$, lithium - up to $0.201 \mathrm{mg} / \mathrm{kg}$, vanadium - up to $0.176 \mathrm{mg} / \mathrm{kg}$, cobalt - up to $0.114 \mathrm{mg} / \mathrm{kg}$, silver- $0.086 \mathrm{mg} / \mathrm{kg}$

Toxic elements lead, cadmium, beryllium, mercury, and thallium were found to be low in milk thistle fruit extract, and their content was found to meet sanitary rules and norms’ №0283 hygienic standards. The results of the analysis are presented in the table below.

\begin{tabular}{|l|l|l|l|}
\hline $\begin{array}{l}\text { Name of macro and } \\
\text { microelements }\end{array}$ & Quantity, mg / kg & $\begin{array}{l}\text { Name of macro and } \\
\text { microelements }\end{array}$ & Quantity, mg / kg \\
\hline Li7 & 0.201 & K 39 & 9469.416 \\
\hline $\mathrm{Be} 9$ & 0.034 & $\mathrm{Ca} \mathrm{42}$ & 6620.220 \\
\hline $\mathrm{B} 11$ & 44.421 & $\mathrm{Ti} 48$ & 8.891 \\
\hline $\mathrm{Na} \mathrm{23}$ & 644.594 & $\mathrm{~V} \mathrm{51}$ & 0.176 \\
\hline $\mathrm{Mg} 24$ & 3741.564 & $\mathrm{Cr} 52$ & 4.296 \\
\hline $\mathrm{Al} \mathrm{27}$ & 79.572 & $\mathrm{Mn} \mathrm{55}$ & 16.816 \\
\hline $\mathrm{Si} 28$ & 195.841 & $\mathrm{Fe} \mathrm{57}$ & 223.128 \\
\hline $\mathrm{P} \mathrm{31}$ & 9477.017 & $\mathrm{Co} \mathrm{59}$ & 0.114 \\
\hline $\mathrm{S} \mathrm{32}$ & 556.628 & $\mathrm{Ni} 60$ & 1.953 \\
\hline $\mathrm{Cu} 60$ & 24.981 & $\mathrm{Sr} 88$ & 26.577 \\
\hline
\end{tabular}




\begin{tabular}{|l|l|l|l|}
\hline Zn 66 & 39.995 & Zr 90 & 0.319 \\
\hline Ga 69 & 0.296 & Nb 93 & 0.006 \\
\hline Ge 74 & 0.003 & Mo 98 & 0.784 \\
\hline As 75 & 0.083 & Ag 107 & 0.086 \\
\hline Se 82 & 0.253 & Cd 111 & 0.348 \\
\hline Rb 85 & 5.647 & In 115 & 0.002 \\
\hline Sb 121 & 0.045 & Pb 208 & 0.592 \\
\hline Cs 133 & 0.012 & Bi 209 & 0.007 \\
\hline Ba 138 & 6.699 & Tl 205 & 0.001 \\
\hline Ta 181 & 0.001 & U 238 & 0.009 \\
\hline W 184 & 0.021 & & \\
\hline Re 187 & 0.007 & & \\
\hline
\end{tabular}

\section{CONCLUSION}

The dry extract of milk thistle fruit contains optimal amounts of flavolignans, amino acids, carbohydrates, proteins and vitamins, as well as trace elements of iron, silicon, zinc, chromium, silver.

Based on the results obtained, it was determined that it is advisable to include milk thistle dry extract in medicines and biologically active supplements in food.

\section{REFERENCES}

[1] Sokolov S.Ya. 2000. Phytotherapy and phytopharmacology: A guide for doctors. - Moscow: Medical News Agency. - $976 \mathrm{p}$.

[2] Nikolaychenko N.V, Mayevsky V.V, Lyashenko Z.D, Amerkhanov Kh.X. 2006. The experience of cultivation of milk thistle spotted on chernozem soils in the conditions of the Saratov right bank // Nontraditional and rare plants, natural compounds and prospects for their use: Materials of the international. Simp. Belovo. - T. 2. - P. 251-253

[3] Alimova Rano, Adilov Bekhzod The Study of the Morphology and Biology of Germination Seeds of Silybum marianum in Condition Syrdarya Region (UZBEKISTAN)

[4] А.В.Скальный, И.А.Рудакий. Биоэлементы в медицине. М.Мир, 2001.-271 с

[5] Ж.Э.Сафаров. Совершенствование процесса вакуумной сушки с инфракрасным нагревом лекарственных трав: 